\title{
PENGARUH GOOD CORPORATE GOVERNANCE DAN CORPORATE SOSIAL RESPONSIBILITY TERHADAP NILAI PERUSAHAAN DENGAN KINERJA KEUANGAN SEBAGAI VARIABEL MEDIASI PADA PERUSAHAAN MISSCELLANEOUS INDUSTRY DI BEI PERIODE 2016-2019
}

\author{
Metalaras Saputri \\ Universitas Negeri Surabaya \\ metalaras.17080574021@mhs.unesa.ac.id \\ Yuyun Isbanah \\ Universitas Negeri Surabaya \\ yuyunisbanah@unesa.ac.id \\ Abstract
}

\begin{abstract}
This study aims to determine the effect of good corporate governance (GCG) and corporate social responsibility (CSR) on companies' value with financial performance listed on the IDX for the 2016-2019 period. This research's object is 19 selected companies in various industrial sectors, with a sample of 76 annual reports that meet the criteria. The data used is the 2016-2019 annual report. The method used is the classical assumption method, multiple linear regression, path analysis method using SPSS version 25. The direct effect study results, $G C G$, an agency composed of management ownership, institutional ownership, and the board of directors, will not significantly impact the value of the company. GCG, which is proxied by the audit committee and CSR, affects firm value and financial performance (ROA), affecting firm value. The indirect effect research shows that ROA has not been able to mediate the effect of $G C G$, which is proxied by managerial ownership, institutional ownership, and commissioners' board.ROA is only able to mediate the effect of CSR on firm value.
\end{abstract}

Keywords: CSR; GCG; financial performance; firm value

\section{PENDAHULUAN}

Nilai perusahaan dapat diartikan nilai pasar, dikarenakan ketika harga saham mengalami peningkatan maka nilai perusahaan akan berdampak pada kemakmuran stockholder (Sondakh \& Morasa, 2019). Manajemen dapat memilih berbagai kebijakan untuk menaikkan nilai perusahaan dengan cara menaikkan kesejahteraan owner dan stockholder (Brigham \& Houston, 2006:43). Meningkatkan harga saham tidak hanya mengharuskan perusahaan untuk memertimbangkan keuntungan, tetapi tingkat risiko dari keuntungan tersebut apakah harus dikembalikan sebagai dividen atau disimpan untuk diinvestasikan kembali. Setiap perusahaan pastinya memiliki tujuan untuk dicapai, akan tetapi maksimalisasi harga saham merupakan suatu tujuan utama (Brigham \& Houston, 2006:19). Menurut Mahendra (2011), harga saham merupakan tolak ukur dari nilai perusahaan. Apabila harga saham tinggi maka semakin besar kemakmuran dari stockholder.

Nilai Price to Book Value (PBV) merupakan alternatif perhitungan untuk nilai perusahaan, di mana PBV menjelaskan berapa besar pasar menambah nilai saham dari suatu perusahaan (Rachman, 2012). Semakin naik rasionya, maka pasar akan tertarik pada prospek perusahaan. PBV juga menjelaskan sejauh mana perusahaan dapat menghasilkan nilai perusahaan yang relatif pada total modal yang akan diinvestasikan. Menurut Fakhrudin \& Hadianto (2001), PBV diartikan sebagai rasio yang menjelaskan bahwa harga saham yang dijual akan lebih rendah atau lebih tinggi dari nilai buku saham tersebut. Tabel 1 adalah bagan PBV sektoral di BEI periode tahun 2016-2019. 
Metalaras Saputri \& Yuyun Isbanah. Pengaruh Good Corporate Governance dan Corporate Social Responsibility terhadap Nilai Perusahaan dengan Kinerja Keuangan sebagai Variabel Mediasi pada Perusahaan Misscellaneous Industry di BEI Periode 2016-2019

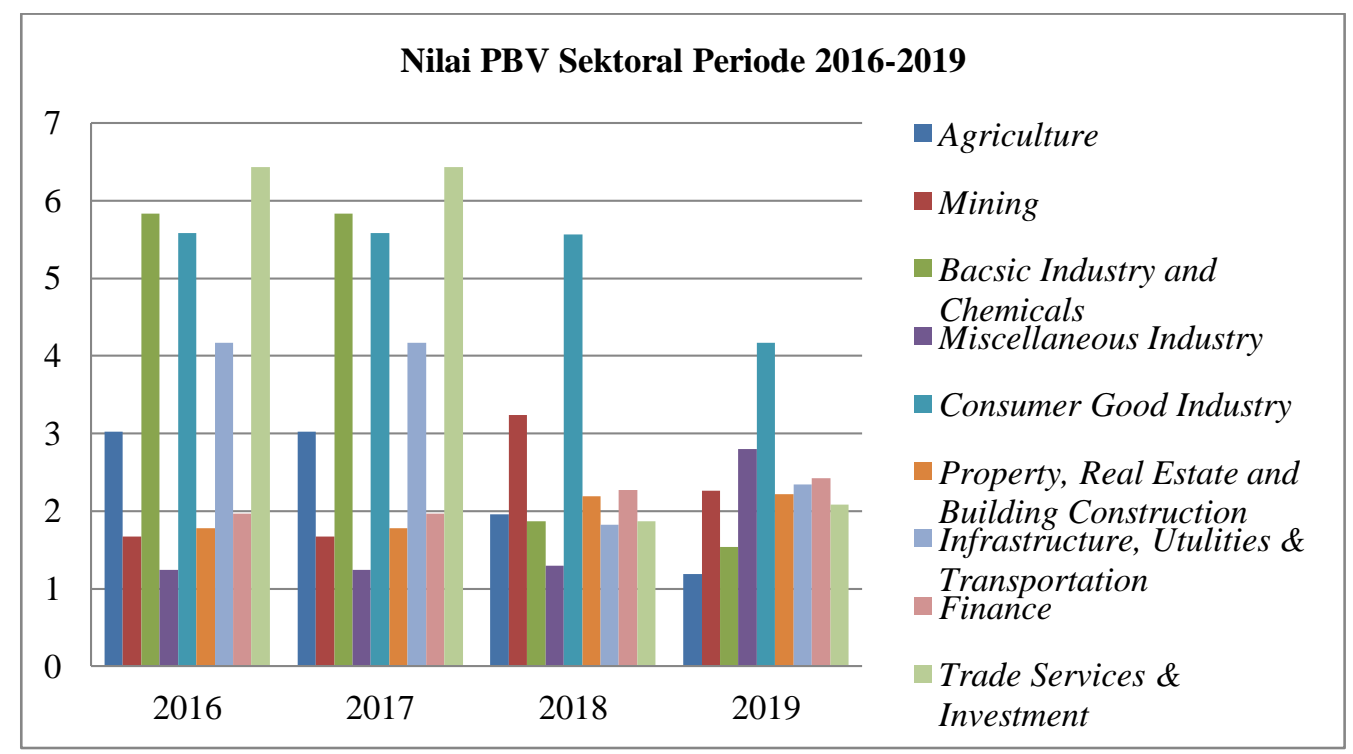

Sumber:Idx.co.id (Diolah penulis, 2020)

\section{Gambar 1. NILAI PBV 9 SEKTOR YANG TERDAFTAR DI BEI PERIODE 2016-2019}

Gambar 1, nilai PBV sektoral di BEI periode 2016-2019. Dari sembilan sector, ada dua sektor perusahaan yang selalu mengalami kenaikan nilai PBV dari tahun 2016-2019 yaitu sektor misscellaneous industry dan sektor finance. Total nilai PBV sektor misscellaneous industry dari tahun 2016-2019 secara berurutan adalah sebagai berikut, 1,24, 1,24, 1,30, dan 2,80. Sedangkan nilai total PBV pada sektor finance dari tahun 2016-2019 secara berurutan adalah sebagai berikut, 1,97, 1,97, 2,27, dan 2,42. Akan tetapi, sektor misscellaneous industry yang memiliki kenaikan signifikan.

Salah satu aspek yang berpengaruh pada nilai suatu perusahaan yaitu Good Corporate Governance (GCG). Menurut Amanti (2012), GCG bisa menaikkan nilai perusahaan, dan perusahaan diharapkan bisa berkinerja dengan baik sehingga menciptakan keuntungan bagi pemegang saham. Keberadaan GCG saat ini tidak hanya menjadi tanggung jawab masing-masing perusahaan, tetapi juga menjadi satu kesatuan yang menghubungkan investor dan manajemen perusahaan (Ratih \& Setyarini, 2014). Kebebasan pemangku kepentingan dalam pengambilan keputusan yang efektif akan diperoleh melalui penerapan tata kelola perusahaan, yang akan meningkatkan nilai perusahaan dan tidak akan menyalahgunakan kekuasaannya untuk kepentingan perusahaan (Chen, 2008). Menurut Juwita (2019), GCG memiliki pengaruh positif signifikan terhadap nilai perusahaan. Susanto \& Ardiani (2016), GCG memiliki pengaruh negatif terhadap nilai perusahaan. GCG tidak memiliki pengaruh terhadap nilai perusahaan (Siahaan, 2013). Menurut Prasatuti \& Budiasih (2015) GCG dapat diproksikan menggunakan variabel kepemilikan manajerial, kepemilikan instritusional, komite audit, dan dewan komisaris independen.

Kepemilikan manajerial merupakan jumlah persentase saham yang dimiliki pihak manajemen yang ikut aktif dalam proses pengambilan keputusan atau seluruh modal dalam perusahaan (Syafitri et al., 2018). Apabila kepemilikan saham pihak manajemen tinggi maka nilai perusahaan juga akan mengalami kenaikan (Sholekah \& Venusita, 2014). Menurut Fatimah et al. (2019) dan Marius \& Masri (2017), kepemilikan manajerial berpengaruh positif terhadap nilai perusahaan. Menurut Purbopangestu \& Subowo (2014), kepemilikan manjerial berpengaruh negatif terhadap nilai perusahaan. Kepemilikan manajerial tidak memiliki pengaruh terhadap nilai perusahaan (Obradovich, 2013) dan (Putra, 2014).

Kepemilikan institusional merupakan kepemilikan saham perusahaan oleh institusi atau lembaga (Muid, 2009). Jika kepemilikan institusional semakin banyak maka supervisi pihak dari luar perusahaan akan semakin kuat, sehingga pengeluaran keagenan akan berkurang dan nilai perusahaan 
akan meningkat (Sari \& Riduwan, 2011). Menurut Putra (2014), kepemilikan instritusional berpengaruh positif terhadap nilai perusahaan. Menurut Marius \& Masri (2017) serta Obradovich (2013), kepemilikan institusional berpengaruh negatif terhadap nilai perusahaan. Kepemilikan institusional tidak memiliki pengaruh terhadap nilai perusah (Maryanti \& Fithri, 2017).

Komite audit merupakan anggota yang bertanggung jawab atas laporan keuangan serta pengendalian internal perusahaan (Muid, 2009). Komite audit memiliki peran untuk melaksanakan rapat periodik untuk membahas permasalahan yang ada di dalam perusahaan, sehingga dapat menambah kepercayaan investor untuk tertarik berinvestasi pada perusahaan (Isti'adah, 2015). Menurut Mukhtaruddin et al. (2014), komite audit berpengaruh positif terhadap nilai perusahaan tidak sejalan dengan Obradovich (2013), komite audit berpengaruh negatif terhadap nilai perusahaan. Komite audit tidak memiliki pengaruh terhadap nilai perusahaan. (Maryanti \& Fithri, 2017).

Dewan komisari independen merupakan inti dari corporate governance yang bertugas untuk menjamin pelaksanaan strategi perusahaan, mengawasi manajemen dalam mengelola perusahaan, serta pelaksanaan akuntabilitas (Syafitri et al., 2018). Dewan komisaris independen mampu melakukan pengawasan secara objektif untuk dapat meningkat kinerja dan nilai perusahaan (Dewi \& Nugrahanti, 2017). Menurut Maryanti \& Fithri (2017), dewan komisaris independen berpengaruh positif terhadap nilai perusahaan tidak sejalan dengan Sunardi (2019), dewan komisaris independen berpengaruh negatif terhadap nilai perusahaan.

Penerapan GCG tidak hanya memberikan dukungan kepada stakeholders, tetapi juga mendukung masyarakat dan lingkungan (Wibowo, 2010). Salah satu perwujudan dari penerapan prinsip GCG adalah penerapan Corporate Social Responsibility (CSR). CSR adalah tanggung jawab sosial perusahaan terhadap lingkungan serta masyarakat. Penerapan CSR diharapkan mampu memberikan dorongan bagi perusahaan untuk lebih maksimal dalam melaksanakan operasionalnya, supaya tidak berdampak negatif terhadap lingkungan sekitar, sehingga bisa menjamin keberlangsungan operasional perusahaan di masa mendatang (Purbopangestu \& Subowo, 2014). Menurut Marius \& Masri (2017) serta Susanto \& Ardiani (2016), CSR berpengaruh positif terhadap nilai perusahaan tidak sejalan dengan Mukhtaruddin et al. (2014), CSR berpengaruh negatif terhadap nilai perusahaan. Sementara menurut Mai (2017), CSR tidak memiliki pengaruh terhadap nilai perusahaan. GCG maupun CSR memiliki potensi terhadap dampak kinerja dan nilai perusahaan. Penerapan GCG dan CSR yang baik dapat menaikkan kinerja keuangan dan kinerja pasar, serta dapat memaksimalkan nilai perusahaan.

Hubungan GCG dan CSR dengan nilai perusahaan diprediksi juga dipengaruhi oleh faktor lain. Menurut Husnan \& Pamudji (2013), mayoritas investor tertarik pada perusahaan yang membagikan data tentang kinerja keuangan yang dilaporkan pada laporan tahuan (annual report). Oleh sebab itu, pada penelitian ini memakai variabel kinerja keuangan untuk variabel perantara yang diprediksi dapat menjadi mediasi pada pengaruh tersebut. Menurut Sugiyono (2013:64), variabel penyela yang berada di antara variabel $\mathrm{X}$ serta $\mathrm{Y}$ sehingga variabel $\mathrm{X}$ tidak langsung memengaruhi variabel $\mathrm{Y}$. Pada penelitian ini diperkirakan kinerja keuangan dapat menjadi variabel mediasi pengaruh GCG dengan nilai perusahaan serta CSR dengan nilai perusahaan. Menurut Suryaningtyas \& Rohman (2019), kinerja keuangan mampu memediasi pengaruh GCG dan CSR terhadap nilai perusahaan. Sementara menurut Ratih \& Setyarini (2014), kinerja keuangan tidak mampu memediasi pengaruh GCG dan CSR terhadap nilai perusahaan. Tujuan penelitian ini untuk menganalisis pengaruh GCG dengan proksi kepemilikan manajerial, kepemilikan institusional, komite audit, dewan komisari independen serta CSR pada nilai perusahaan dengan proksi Tobin's Q dengan kinerja keuangan yang diproksikan oleh ROA sebagai variabel mediasi pada perusahaan sektor misscellaneous industry di BEI.

\section{KAJIAN PUSTAKA DAN PENGEMBANGAN HIPOTESIS}

\section{Agency Theory}

Agency theory didefinisikan semua individu yang bertindak sesuai dengan kepentingan pribadinya yang pada umumnya dianggap sebagai benturan kepentingan dalam perusahaan (Sudana, 2011). 
Metalaras Saputri \& Yuyun Isbanah. Pengaruh Good Corporate Governance dan Corporate Social Responsibility terhadap Nilai Perusahaan dengan Kinerja Keuangan sebagai Variabel Mediasi pada Perusahaan Misscellaneous Industry di BEI Periode 2016-2019

Selisih kepentingan antara manajemen dengan pemilik atau investor akan mengakibatkan konflik keagenan (Meridelima \& Isbanah, 2021). Jika pemilik perusahaan dapat memberikan insentif, maka manajemen dapat bertindak sesuai dengan keinginan pemilik perusahaan. Pada saat yang sama, pengelola eksternal seperti lembaga memiliki hak kontrol yang kuat, sehingga dapat mengawasi dan mengelola untuk menghindari tindakan oportunistik. Menurut Sudana (2011) berbagai upaya untuk mengurangi masalah keagenan dapat menyebabkan peningkatan biaya keagenan. Agency theory dalam penelitian ini digunakan untuk menjelaskan variabel kepemilikan manajerial, kepemilikan institusional, komite audit, dan dewan komisaris independen.

\section{Stakeholder Theory}

Stakeholder adalah pihak internal ataupun ekstenal yang turut memengaruhi maupun dipengaruhi oleh sesuatu industri secara langsung ataupun tidak langsung (Hadi, 2011). Stakeholder yang dimaksud adalah pihak yang mempunyai hak atas tanggung jawab dari suatu perusahaan. Menurut Astutik (2021), perusahaan wajib membangun serta mempertahankan hubungan yang baik dengan para stakeholder. Stakeholder theory dalam penelitian ini digunakan untuk menjelaskan variabel corporate social responsibility (CSR)

\section{Signaling Theory}

Menurut Brigham \& Houston (2006), signaling theory merupakan teori tentang cara suatu perusahaan dalam melakukan aksi untuk memberikan suatu data atau informasi pada investor tentang pandangan manajemen kepada tujuan perusahaan pada masa selanjutnya. Dari data tersebut maka para investor akan menggunakannya dalam pengambilan keputusan investasi (Sudana, 2011). Signaling theory dalam penelitian ini digunakan untuk menjelaskan variabel kinerja keuangan (ROA) sebagai variabel mediasi.

\section{Good Corporate Governance (GCG)}

GCG didefinisikan tata cara dengan peran untuk mengatur serta menyusun suatu perusahaan yang membagikan nilai tambah untuk stakeholder (Monks \& Minow, 2003). Pelaksanaan GCG adalah salah satu aspek penting dalam upaya kenaikan nilai perusahaan serta menarik perhatian calon pemegang saham dikarenakan sudah melakukan minimalisasi risiko dalam pengambilan keputusan sehingga nilai perusahaan akan mengalami peningkatan (Krisnando \& Sakti, 2019). Mekanisme GCG dibagi ke dalam dua kelompok yaitu internal dan eksternal. Menurut Iskandar \& Chamlou (2000), mekanisme internal seperti komposisi dewan komisaris, rapat umum, sekretaris perusahaan, struktur kepemimpinan, dan dewan direksi. Sebaliknya mekanisme eksternal merupakan metode memengaruhi perusahaan tidak hanya dengan memakai mekanisme internal perusahaan.

\section{Kepemilikan Manajerial (KM)}

Kepemilikan manajerial merupakan saham manajemen yang ikut berperan saat penentuan tujuan perusahaan (Muid, 2009). Salah satu fungsi kepemilikan manajerial yaitu menyetarakan antara kepentingan pemegang saham dengan manajemen, sebagai akibat dari konsekuensi Ipengambilan keputusan yang menjadi tanggung jawab kedua belah pihak secara adil sehingga tidak terdapat pihak yang dirugikan (Mukhtaruddin et al., 2014). Menurut Sari (2017), kepemilikan manajerial dihitung dengan persamaan (1).

$$
K M=\frac{\text { Jumlah saham yang dimiliki manajemen }}{\text { Total saham beredar }} \times 100 \%
$$

\section{Kepemilikan Institusional (KI)}

Menurut Muid (2009), kepemilikan institusional mempunyai kemampuan untuk menurunkan bonus pihak manajemen yang memikirkan kepentingan diri sendiri dengan taraf supervisi yang intensif dan bisa menekan ketergantungan manajemen untuk menggunakan kebijakan pada laporan keuangan sehingga memengaruhi mutu keuntungan yang dilaporkan. Menurut Sari (2017) kepemilikan institusional dapat dilihat pada persamaan (2). 
$K I=\frac{\text { Jumlah saham yang dimiliki institusional }}{\text { Total saham beredar }} \times 100$.

\section{Komite Audit (KA)}

Komite audit bertanggung jawab sebagai pengawas antara lain pengawasan kepada laporan keuangan, audit eksternal serta mekanisme pengendalian internal (Muid, 2009). Menurut Kristanti \& Syafuddin (2012), untuk melaksanakan tanggung jawabnya yang terdiri dari monitoring seluruh aktivitas perusahaan agar tercapai secara maksimal maka jumlah anggota komite audit harus terpenuhi. Menurut Sari (2017), komite audit dapat dilihat pada persamaan (3).

$K A=J u m l a h$ anggota komite audit

\section{Dewan Komisaris Independen (DKI)}

Komisaris independen adalah badan yang tidak berhubungan keluarga atau bisnis dengan pihak berkepentingan dalam perusahaan, maka dari itu komisaris independen bertugas hanya melindungi kepentingan para pemegang saham (Raja, 2016). Dewan komisaris independen bertanggung jawab untuk meningkatkan peranan dewan komisaris untuk mewujudkan tata kelola perusahaan yang baik. (Siahaan, 2013) Menurut Afzal \& Rohman (2012), dewan komisaris independen dapat dilihat pada persamaan (4).

$D K I=\frac{\text { Jumlah komisaris independen }}{\text { Jumlah seluruh } \text { komisaris }} \times 100 \%$

\section{Corporate Social Responsibility (CSR)}

CSR didefinisikan salah satu tujuan di dalam dunia bisnis untuk ikut serta terhadap kemajuan ekonomi berkelanjutan, salah satu cara yang ditunjukkan adalah memberikan perhatian dalam bentuk tanggung jawab sosial perusahaan serta menfokuskan pada kesetaraan terhadap aspek sosial, ekonomi, dan lingkungan (Untung, 2008). Menurut Ardianto \& Machfudz (2011), CSR merupakan standar yang seharusnya dilakukan sesuai dengan tujuan perusahaan agar berjalan secara legal, etis, dan turut serta berkontribusi untuk meningkatkan kualitas hidup para karyawan serta masyarakat luas. CSR merupakan cara perusahaan untuk melakukan pencapaian keseimbangan dari ekonomi, enviroment atau lingkungan, serta masalah-masalah sosial dalam kurun waktu yang bersamaan yang tentunya dapat memenuhi ekspektasi shareholder dan stakeholder (Nova, 2012). Menurut Haniffa (2005), CSR dapat dilihat pada persamaan (5).

$C S R I=\frac{\sum X i j}{n j}$

\section{Kinerja Keuangan}

Menurut Yahya (2014), kinerja keuangan adalah salah satu faktor investor untuk berinvestasi di suatu perusahaan dengan cara melihat kinerja dari perusahaan tersebut. Kinerja keuangan adalah kajian yang dilaksanakan untuk mengetahui seberapa jauh perusahaan melakukan dan menggunakan peraturan-peraturan keuangan secara efektif dan efisien. (Fahmi, 2011), Menurut Brigham \& Houston (2006), kinerja keuangan yang diproksikan oleh ROA pada persamaan (6).

$R O A=\frac{\text { Laba bersih setelah pajak }}{\text { Total asset }} \times 100 \%$

\section{Nilai Perusahaan}

Menurut Puspita (2011), harga saham kerap dikaitkan dengan cara pandang investor untuk melihat nilai perusahaan. Harga saham yang besar dapat menghasilkan nilai perusahaan yang besar, sehingga harga saham menjadi gambaran bagi perusahaan untuk menjaga kestabilan dan peningkatan nilai perusahaan (Wiranoto, 2021). Tobin's Q merupakan rasio dari nilai pasar asset perusahaan yang diukur oleh nilai pasar dari jumlah saham yang beredar dan hutang terhadap biaya penggantian (replacement cost) dari aktiva perusahaan (Syafitri et al., 2018). Menurut Lindenberg \& Ross (1981), nilai perusahaan yang diproksikan oleh Tobin's Q. pada persamaan (7). 
Metalaras Saputri \& Yuyun Isbanah. Pengaruh Good Corporate Governance dan Corporate Social Responsibility terhadap Nilai Perusahaan dengan Kinerja Keuangan sebagai Variabel Mediasi pada Perusahaan Misscellaneous Industry di BEI Periode 2016-2019

Tobin's $Q=\frac{E M V+D}{T A}$.

\section{Pengaruh antar Variabel}

Agency theory merupakan dasar pengaruh kepemilikan manajerial terhadap nilai perusahaan, karena masalah keagenan dapat menghambat maksimalisasi nilai perusahaan (Astutik, 2021). Kepemilikan manajerial berdampak positif tidak signifikan pada nilai perusahaan. Dikarenakan kepemilikan manajerial tidak bisa dilihat sebagai sistem yang sesuai guna menekan selisih kepentingan yang terjadi oleh pemilik dan manajer (Nurhayati \& Medyawati 2012) dan (Wongso, 2013). Menurut Sholekah \& Venusita (2014), kepemilikan manajerial memiliki pengaruh positif signifikan pada nilai perusahaan. Artinya semakin banyak saham pihak manajemen perusahaan maka akan tinggi nilai perusahaan tersebut, sebab perbandingan kepemilikan saham yang dikendalikan oleh pengaruh manajemen akan memengaruhi kebijakan perusahaan, sehingga menyamakan keuntungan antara manajemen dan pemegang saham, sehingga mengurangi biaya keagenan dan meningkatkan nilai perusahaan. Hasil itu sejalan dengan Fatimah et al., (2019) dan Marius \& Masri (2017).

H1: Ada pengaruh positif kepemilikan manajerial terhadap nilai perusahaan.

Agency theory menjadi dasar pengaruh kepemilikan institusional terhadap nilai perusahaan, karena kepemilikan institusional dapat mengurangi biaya keagenan sehingga dapat meningkatkan nilai perusahaan (Astutik, 2021). Kepemilikan institusional secara positif tidak signifikan memengaruhi nilai perusahaan. Hal ini dikarenakan sebagian besar pemilik investor cenderung bekerjasama dengan manajemen dan membiarkan keinginan investor kecil (Isti'adah, 2015) dan (Permanasari, 2010). Menurut Sari \& Riduwan (2011) serta Nuraina (2012), kepemilikan institusional secara positif signifikan memengaruhi nilai perusahaan, dikarenakan semakin banyak kepemilikan institusional akan kuat supervisi pihak luar pada perusahaan. Oleh karena itu, pengeluaran keagenan yang digunakan dalam perusahaan menjadi berkurang dan nilai perusahaan akan mengalami peningkatan. Hasil itu sejalan dengan Putra (2014).

H2: Ada pengaruh positif kepemilikan institusional terhadap nilai perusahaan.

Agency theory menjelaskan bahwa komite audit mampu menyelesaikan masalah keagenan karena memiliki fungsi pengendalian internal. Komite audit secara positif tidak signifikan memengaruhi nilai perusahaan (Astutik, 2021). Sebab komite audit bukan satu-satunya aspek dalam menaikkan efektivitas kegunaan komite audit, terutama terkait konflik kepentingan, perilaku merugikan perusahaan, dan penyelewengan (Hariarti \& Rihatiningtyas, 2015) serta (Obradovich, 2013). Menurut Isti'adah (2015), komite audit memengaruhi nilai perusahaan. Pasalnya, kehadiran audit berperan untuk melaksanakan pertemuan rutin untuk membahas masalah-masalah besar, agar dapat menambah rasa percaya calon investor terhadap investasi saham perusahaan. Hasil itu sejalan dengan Mukhtaruddin et al., (2014).

H3: Ada pengaruh positif komite audit terhadap nilai perusahaan.

Menurut agency theory, komisaris independen mampu bekerja sebagai mediator untuk mengurangi perkara keagenan karena komisaris independen tidak mempunyai hubungan dengan pengurus ataupun penanam saham (Astutik, 2021). Komisaris mampu memberikan pengawasan yang obyektif untuk mendukung kinerja perusahaan. Pengawasan semacam ini mengarah pada laporan keuangan yang lebih baik, maka investor akan minat untuk menanamkan modalnya pada perusahaan (Dewi \& Nugrahanti, 2017). Hasil penelitian Putra (2015), menunjukkan dewan komisaris independen berpengaruh terhadap nilai perusahaan. Sejalan dengan Maryanti \& Fithri (2017). Sedangkan menurut Sunardi (2019), dewan komisaris independen berpengaruh negatif terhadap nilai perusahaan.

H4: Ada pengaruh positif dewan komisaris independen terhadap nilai perusahaan. 
CSR secara positif tidak signifikan memengaruhi nilai perusahaan. Hal ini dikarenakan penyampaian CSR di dalam perusahaan tidak serta merta menambah nilai suatu perusahaan, (Dian \& Lidyah, 2012) serta (Nurhayati \& Medyawati, 2012). Sejalan dengan stakeholder theory, bahwa perusahaan harus ikut berkontribusi dalam masyarakat dan memberi manfaat untuk lingkungan sekitar (Astutik, 2021). Menurut Hariarti \& Rihatiningtyas (2015), peningkatan penyampaian CSR perusahaan akan membentuk citra positif bagi perusahaan sehingga investor dapat melihatnya sebagai investasi pada perusahaan. Selain itu, apaila perusahaan manufaktur memerhatikan tata kelola lingkungan, masyarakat akan menilai positif kepada perusahaan tersebut. Hasil itu didukung Marius \& Masri (2017) dan Susanto \& Ardiani (2016).

H5: Ada pengaruh positif CSR terhadap nilai perusahaan.

Berdasarkan signalling theory, para investor akan memeroleh sinyal positif terkait kinerja keuangan dalam peningkatan laba (Astutik, 2021). Kinerja keuangan secara positif memengaruhi nilai perusahaan, ditunjukkan dengan nilai perusahaan akan semakin baik ketika kinerja keuangan tinggi (Pertiwi \& Pratama, 2012). Hasil lain menunjukkan apabila kinerja keuangan tinggi maka memiliki pengaruh negatif terhadap perusahaan (Wedayanthi \& Darmayanti, 2016). Sepakat dengan pernyataan yang disampaikan oleh Modigliani \& Miller (1958), suatu nilai perusahaan dapat dipastikan oleh kekuatan suatu perusahaan, hasil negatif ini memerlihatkan ketika earning power kecil maka perputaran aktiva akan semakin efisien atau dapat diartikan juga semakin kecil margin yang didapatkan perusahaan maka nilai perusahaan akan turun.

H6: Ada pengaruh positif kinerja keuangan terhadap nilai perusahaan.

Berdasarkan signalling theory jika kinerja keuangan perusahaan naik, maka harga saham perusahaan dapat naik (Suryaningtyas \& Rohman, 2019). Oleh karena itu, peningkatan kinerja keuangan menunjukkan bahwa status keuangan perusahaan dalam keadaan baik (Irawan \& Devie, 2017). Menurut Jensen (1976), nilai perusahaan terpengaruhi oleh pembagian kepemilikan manajer yang dieksploitasi oleh pihak eksternal dan yang tidak dieksploitasi oleh pihak internal. Kepemilikan manajerial yang lebih tinggi dapat mengurangi kesulitan agensi dengan mengurangi insentif untuk mengambil kekayaan pemegang saham untuk memanfaatkan keuntungan (Astutik, 2021). Kinerja keuangan dapat memediasi pengaruh kepemilikan manajerial terhadap nilai perusahaan (Wulan, 2016). Hasil berbeda oleh Astutik (2021), kinerja keuangan tidak mampu memediasi pengaruh kepemilikan manajerial terhadap nilai perusahaan.

H7: Kinerja keuangan mampu memediasi pengaruh kepemilikan manajerial terhadap nilai perusahaan.

Kepemilikan institusional adalah pemegang saham mayoritas perusahaan (Muid, 2009). Besarnya kepemilikan institusional yang dapat dilihat pada laporan keuangan yang digunakan untuk memudahkan calon investor dalam mengevaluasi perusahaan (Marius \& Masri, 2017). Berdasarkan agency theory terdapat ketidaksesuaian informasi anatara manajemen dan pemilik perusahaan (Astutik, 2021). Menurut Sukirni (2012) dan Thaharah \& Asyik (2016), kepemilikan institusional berpengaruh pada nilai perusahaan, sebab jika kepemilikan institusional tinggi, penggunaan aset perusahaan akan semakin efisien. Hasil tidak sejalan dengan Astutik (2021), kinerja keuangan tidak mampu memediasi pengaruh kepemilikan institusional terhadap nilai perusahaan.

H8: Kinerja keuangan mampu memediasi pengaruh kepemilikan institusional terhadap nilai perusahaan.

Berdasarkan agency theory komite audit dalam perusahaan sangat dibutuhkan untuk mengurangi kecurangan yang dilakukan oleh pihak manajemen (Astutik, 2021). Menurut Chrisdianto (2013), komite audit memiliki peran penting di dalam suatu perusahaan salah satu tanggung jawabnya adalah memberikan suatu pendapat tentang laporan serta hal lainnya kepada dewan komisaris. Menurut 
Metalaras Saputri \& Yuyun Isbanah. Pengaruh Good Corporate Governance dan Corporate Social Responsibility terhadap Nilai Perusahaan dengan Kinerja Keuangan sebagai Variabel Mediasi pada Perusahaan Misscellaneous Industry di BEI Periode 2016-2019

Kusumaningtyas (2015), komite audit memengaruhi nilai perusahaan dikarenakan jika kualitas dari pihak audit tinggi maka komite audit akan bertanggung jawab dalam melakukan perlindungan terhadap pemegang saham minoritas mampu menyakinkan kepada investor untuk berinvestasi di perusahaan tersebut. Tidak sejalan dengan (Syafitri et al., 2018) serta Suryaningtyas \& Rohman (2019), proporsi komite audit belum menjadi jaminan keefektifan dari kinerja komite audit saat melaksanakan pengawasan terhadap kinerja keuangan. Hal itu dikarenakan komite audit tidak saja melakukan pengawasan di bidang keuangan namun juga melakukan pengawasan di bidang non keuangan serta melaksanakan rapat secara periodik untuk mempertahankan citranya dimata para investor.

H9: Kinerja keuangan mampu memediasi pengaruh komite audit terhadap nilai perusahaan.

Menurut, agency theory, dewan komisaris independen mampu mengatasi masalah keagenan karena peran yang dilakukan lebih objektif terhadap peningkatan nilai perusahaan (Astutik, 2021). Apabila total anggota komisaris independen semakin banyak maka dapat meningkatkan nilai perusahaan. Dikarenakan dewan komisaris independen mampu menaikkan kegiatan pengawasan sehingga mengurangi terjadinya manipulasi (Purbopangestu \& Subowo, 2014). Kinerja keuangan tidak memoderasi hubungan dewan komisaris independen dengan nilai perusahaan. Apabila komposisi komisaris independen banyak maka sulit bagi perusahaan untuk mengambil keputusan, sehingga perlu waktu lama untuk memertimbangkan peningkatan laba dan nilai perusahaan (Astutik, 2021). Hasil ditolak oleh Suryaningtyas \& Rohman (2019), kinerja keuangan mampu memediasi pengaruh komisaris independen terhadap nilai perusahaan.

H10: Kinerja keuangan mampu memediasi pengaruh dewan komisaris independen terhadap nilai perusahaan.

Menurut Maryanti \& Tjahjadi (2013), perusahaan dapat melakukan pengungkapan CSR dengan maksud untuk memeroleh validasi dan evaluasi baik dari masyarakat. Masyarakat menganggap perusahaan sebagai perusahaan yang baik dikarenakan perusahaan tidak saja berfokus terhadap keuntungan, namun perusahaan juga fokus pada bidang sosial sekitar perusahaan (Haryati \& Raharjo, 2013). Sejalan dengan stakeholder theory bahwa untuk dapat meningkatkan nilai perusahaan masa mendatang maka perusahaan harus berperilaku etis dalam melaksanakan tanggung jawab sosial di lingkungan sekitar, sehingga akan menghasilkan dampak positif serta mencerminkan keuntungan dari perusahaan (Ghozali \& Chariri, 2007). Hal tersebut dapat menghasilkan feedback yang baik bagi perusahaan sehingga berdampak pada kinerja perusahaan yang mengalami peningkatan. Tanggung jawab sosial perusahaan memiliki pengaruh yang signifikan pada nilai perusahaan, dan kinerja keuangan secara signifikan memengaruhi nilai perusahaan (Maryanti \& Tjahjadi, 2013). Hasil lain menyatakan kinerja keuangan tidak mampu memediasi penagruh CSR terhadap nilai perusahaan (Astutik, 2021).

H11: Kinerja keuangan mampu memediasi pengaruh CSR terhadap nilai perusahaan.

\section{METODE PENELITIAN}

Penelitian ini merupakan penelitian kausalitas yang menggunakan data kuantitatif. Variabel independen terdiri dari GCG yang diprosikan (kepemilikan manajerial, kepemilikan institusional, komite audit, dan dewan komisaris independen) serta CSR. Variabel independen adalah nilai perusahaan dan variabel mediasi adalah kinerja keuangan. Pengumpulan data memakai teknik dokumentasi dengan sumber dari data sekunder di BEI. Populasi dalam penelitian ini yaitu perusahaan-perusahaan pada perusahaan sektor miscellaneous industry di BEI dari tahun 2016-2019. Sampel sebanyak 76 perusahaan diambil dari 136 perusahaan dengan menggunakan teknik purposive sampling. Kriteria yang ditetapkan meliputi perusahaan yang mempunyai laporan tahunan dan laporan keuangan lengkap selama periode 2016-2019, dan perusahaan yang telah mengalami laba selama 2 tahun atau lebih selama periode 2016-2019. Penelitian ini memakai analisis jalur (path 
analysis) dengan program SPSS 25. Pengujian dilaksanakan dalam dua tahap. Tahap awal adalah uji statistik regresi untuk mengetahui berpengaruh atau tidaknya variabel $\mathrm{X}$ dan $\mathrm{Y}$. Tahap berikutnya, analisi jalur (path analysis), untuk memastikan pengaruh langsung atau tidak pada model dan varibel.

\section{HASIL DAN PEMBAHASAN}

\section{Uji Asumsi Klasik}

Berdasarkan uji normalitas diperoleh nilai KS sebesar 0,671 dan probabilitas 0,200>0,05, sehingga data disebut normal. Hasil uji mltikolonialitas dari semua variabel $X$ nilai toleransinya $>0,10$ dengan VIF $<10$. Maka dari itu model regresi bisa disebut tidak multikolonieritas. Uji autokorelasi dengan running test $0,758>0,05$, tidak terdapat tanda autokorelasi pada data tersebut. Uji heteroskedastisitas memakai scatter plot terlihat bahwa titik residual berdistribusi sekitaran 0 , dan tidak ada pola oleh karena itu, tidak terjadi heteroskedastisitas pada model regresi.

\section{Uji Hipotesis}

Tabel 1.

\section{UJI HIPOTESIS 1}

\begin{tabular}{lllll}
\hline & B & T & Sig. & Keterangan \\
\hline Adjusted R Square & & & 0,244 & \\
Uji F & & & 0,000 & Berpengaruh \\
Uji t & & & & \\
(Constant) & 2614472,706 & 1,791 & 0,078 & \\
KM & 1457250,434 & 1,569 & 0,121 & Tidak \\
KI & 102567,681 & 0,357 & 0,722 & Tidak \\
KA & $-1083158,772$ & $-2,218$ & 0,030 & Berpengaruh \\
DKI & 253694,422 & 0,334 & 0,739 & Tidak \\
CRSI & 2986580,721 & 3,274 & 0,002 & Berpengaruh \\
ROA & 2377055,585 & 2,617 & 0,011 & Berpengaruh \\
\hline
\end{tabular}

Sumber:Output SPSS (2021)

Tabel 1. merupakan pengujian koefisien determinasi, uji F, serta uji t. Nilai Adjusted $R$ Square adalah $24,4 \%$ artinya $24,4 \%$ dari nilai perusahaan dapat dijelaskan oleh variabel $\mathrm{X}$ dalam penelitian, dan 75,6\% lainnya dijelaskan oleh faktor lain. Pada uji $\mathrm{F}$ nilai $\mathrm{F}$ hitung $0,00<0,05$ artinya variabel independen bersama-sama memengaruhi nilai perusahaan. Uji t menunjukkan bahwa signifikansi $\leq$ 0,05 oleh karena itu hipotesis diterima. Dalam pengujian ini terdapat tiga asumsi yang diterima yaitu komite audit (KA), CSR, dan kinerja keuangan (ROA) dan sisanya ditolak karena tidak memenuhi kriteria.

Tabel 2.

\section{UJI HIPOTESIS 2}

\begin{tabular}{lllll}
\hline & B & T & Sig. & Keterangan \\
\hline $\begin{array}{l}\text { Adjusted R Square } \\
\text { Uji F }\end{array}$ & & 0,223 & \\
Uji t & & 0,000 & Berpengaruh \\
(Constant) & $-0,123$ & $-0,640$ & 0,524 & Tidak \\
KM & 0,057 & 0,470 & 0,640 & Tidak \\
KI & $-0,012$ & $-0,318$ & 0,751 & Tidak \\
KA & $-0,009$ & $-0,133$ & 0,894 & Tidak \\
DKI & 0,393 & 4,464 & 0,000 & Berpengaruh \\
CRSI & 0,351 & 3,126 & 0,003 & Berpengaruh \\
\hline
\end{tabular}

Sumber:Output SPSS (2021) 
Metalaras Saputri \& Yuyun Isbanah. Pengaruh Good Corporate Governance dan Corporate Social Responsibility terhadap Nilai Perusahaan dengan Kinerja Keuangan sebagai Variabel Mediasi pada Perusahaan Misscellaneous Industry di BEI Periode 2016-2019

Tabel 2. menunjukkan nilai Adjusted $R$ Square adalah 22,3\% artinya $22.3 \%$ kinerja keuangan dipengaruhi oleh variabel independen dan sisanya 77,7\% dipengaruhi faktor lain. Uji F menunjukkan $\mathrm{F}$ hitung sebesar $0,000<0,05$ berarti variabel independen bersama-sama mampu memengaruhi kinerja keuangan. Hasil uji t menunjukkan ada dua variabel yang memengaruhi kinerja keuangan yaitudewan komisaris independen dan CSR.

Tabel 3.

SOBEL TEST

\begin{tabular}{llll}
\hline & t hitung & t tabel & Keterangan \\
\hline KM-ROA-TOBIN'S Q & 0,023 & 1,96 & Tidak \\
KI-ROA-TOBIN'S Q & $-0,101$ & 1,96 & Tidak \\
KA-ROA-TOBIN'S Q & 0,116 & 1,96 & Tidak \\
DKI-ROA-TOBIN'S Q & 0,000 & 1,96 & Tidak \\
CSR-ROA-TOBIN'S Q & 3,136 & 1,96 & Memediasi \\
\hline
\end{tabular}

Sumber:Output Sobel Test (2021)

Tabel 3 menunjukkan hasil dari sobel test. ROA hanya dapat memediasi pengaruh CSR terhadap Tobin's Q, dan ROA tidak mampu memediasi pengaruh variabel lainnya.

\section{Pengaruh Kepemilikan Manajerial terhadap Nilai Perusahaan}

Pada pengujian hipotesis membuktikan kepemilikan manajerial tidak memiliki pengaruh pada nilai perusahaan, sehingga H1 ditolak. Hasil ini tidak sesuai dengan agency theory. Kepemilikan saham manajemen mampu mereduksi permasalahan keagenan sebab mampu menyeimbangkan berbagai macam kepentingan yang ada di dalam perusahaan (Astutik, 2021). Namun, pada data penelitian jumlah persentase kepemilikan saham oleh pihak manajemen di perusahaan misscellaneous industry di BEI periode 2016-2019 adalah sebesar 8\%. Di mana dengan jumlah rata-rata persentase yang rendah maka pihak manajemen tidak dapat bertindak sesuai dengan keinginan para investor dan belum mampu mangurangi masalah yang terjadi dalam perusahaan. Hasil tersebut didukung oleh perusahaan AUTO, BIMA, ESTI, GDYR, IMAS, INDR, INDS, KBLI, dan SRIL pada periode penelitian jumlah kepemilikan manajerial sebesar 0\%. Sehingga kepemilikan manajerial belum mampu dinilai sebagai sistem yang sesuai untuk dapat menurunkan konflik antara pihak pemilik dengan pihak manajer. Hasil ini sejalan dengan Nurhayati \& Medyawati (2012), Wongso (2013), dan Astutik (2021). Interpretasi praktis hasil ini supaya perusahaan memperbanyak persentase kepemilikan saham oleh pihak manajemen supaya bisa bertindak sesuai keinginan investor yang dampaknya nilai perusahaan akan meningkat.

\section{Pengaruh Kepemilikan Institusional terhadap Nilai Perusahaan}

Pada pengujian hipotesis, kepemilikan institusional tidak memiliki pengaruh pada nilai perusahaan, sehingga $\mathrm{H} 2$ ditolak. Hasil ini ditolak agency theory, kepemilikan institusional dapat mengecilkan biaya keagenan sehingga mampu menaikkan nilai perusahaan tersebut (Astutik, 2021). Namun, pada data penelitian jumlah rata-rata kepemilikan saham pihak investor institusional yang merupakan pemilik saham mayoritas sebesar 58\%. Di mana dengan besarnya deviden yang dibagikan kepada pemegang saham akan berpengaruh terhadap menurunnya total laba ditahan sehingga dapat mengurangi dana internal perusahaan agar dapat memajukan perusahaan, sehingg dapat menjatuhkan nilai saham itu sendiri. Didukung oleh perusahaan AMIN, ASII, AUTO, BIMA, BOLT, ESTI, GDYR, IMAS, INDR, INDS, dan KBLI yang memiliki jumlah kepemilikan institusional selama periode penelitian diatas 50\% Faktor lain dipicu oleh kepemilikan institusional yang tidak mampu maksimal dalam melaksanakan kontrol terhadap kinerja dari pihak manajemen. Sehingga pihak manajemen dapat melakukan penentuan keputusan-keputusan yang bertujuan untuk mengutamakan dirinya sendiri dan kemakmuran dari pemegang saham akan diabaikan yang berdampak pada penurunan nilai perusahaan dikarenakan pasar tidak memberikan respon yang baik terhadap perusahaan tersebut. Hasil ini sejalan dengan Wongso (2013), Hariarti \& Rihatiningtyas (2015), 
Marius \& Masri (2017), serta Astutik (2021). Interpretasi praktis penelitian ini adalah supaya perusahaan melakukan pengawasan untuk menjaga kemakmuran supaya tidak ada pihak yang merasa dirugikan oleh salah satu pihak yang mendominasi untuk kepentingannya sendiri.

\section{Pengaruh Komite Audit terhadap Nilai Perusahaan}

Pada pengujian hipotesis, komite audit memiliki pengaruh pada nilai perusahaan, sehingga $\mathrm{H} 3$ diterima. Penelitian ini sesuai dengan agency theory. Teori keagenan menunjukkan bahwa komite audit dapat menyelesaikan masalah keagenan karena memiliki fungsi pengendalian internal, dan jika jumlah anggota yang cukup maka pengendalian dari komite audit juga dapat dilakukan. dengan tepat (Astutik, 2021). Dalam data penelitian, rata-rata jumlah komite audit pada perusahaan sektor miscellaneous industry di BEI periode 2016-2019 adalah 3 orang. Hal tersebut didukung Peraturan OJK No 55/POJK.04/2015 yang mengatur sekurang-kurangnya 3 orang anggota komite audit. Faktor lainnya dipicu oleh adanya komite audit dan tugasnya dalam rapat rutin untuk membahas permasalahan perusahaan. Sehingga dengan melakukan rapat secara periodik dapat meningkatkan rasa percaya investor untuk berinvestasi pada perusahaan tersebut. Selain itu komite audit mampu melaksanakan pengawasan terhadap pihak manajemen di bidang keuangan ataupun non keuangan. Penelitian ini sejalan dengan Isti'adah (2015), dan Effendi (2016). Interpretasi praktis hasil ini supaya tetap memertahankan total komite audit yang minimal 3 orang supaya dapat bekerja secara maksimal dan tetap melakukan rapat periodik untuk dapat meningkatkan kepercayaan masyarakat dan nilai perusahaan.

\section{Pengaruh Dewan Komisaris Independen terhadap Nilai Perusahaan}

Berdasarkan uji hipotesis, komisaris independen tidak memiliki pengaruh terhadap nilai perusahaan, maka H4 ditolak. Penelitian ini tidak didukung agency theory, jumlah dewan komisaris independen mampu menangani permasalahan keagenan, dikarenakan selama jumlah anggotanya cukup maka fungsi pengawasan dapat terlaksana dengan baik. Menurut UUPT Pasar ayat 1 ayat 2 ayat ini mengatur bahwa suatu perusahaan memiliki paling sedikit satu orang anggota komite independen (Astutik, 2021). Namun dalam data penelitian pada perusahaan misscellaneous industri di BEI periode 2016-2019, rata-rata jumlah komisaris independen adalah 5-7 orang. Semakin besar jumlah komisaris independen maka nilai perusahaan akan rendah karena terlalu banyak faktor yang dipertimbangkan dalam pengambilan keputusan yang membuatnya tidak valid. Faktor lainnya adalah kegagalan dewan komisaris independen dalam menjalankan fungsi pengawasannya dengan baik di dalam kepengurusan. Sehingga memungkinkan terjadinya manipulasi dalam penyajian laporan keuangan serta belum mampu mengendalikan sehingga nilai perusahaan akan turun. Hasil ini sejalan dengan Astutik (2021) dan Sunardi (2019). Interpretasi praktis hasil ini adalah agar perusahaan memerhatikan komposisi dewan komisaris independen pada suatu perusahaan.

\section{Pengaruh CSR terhadap Nilai Perusahaan}

Berdasarkan pengujian uji hipotesis, CSR memiliki pengaruh pada nilai perusahaan, sehingga H5 diterima. Hasil ini didukung stakeholder theory yang menyatakan semua pihak berhak mendapatkan tanggung jawaban dari perusahaan (Astutik, 2021). Pada data penelitian jumlah rata-rata persentase pengungkapan CSR adalah sebesar $16 \%$ yang didominasi oleh perusahaan ASSI, KBLI, KBLM, RICY, dan SMSM di mana tingkat pengungkapan CSR diatas rata-rata. Maka dari itu, perusahaan harus menjaga hubungan terhadap shareholder, namun juga memertimbangkan kepentingan stakeholder. Sehingga apabila CSR yang dilaksanakan sesuai maka akan membuat perusahaan semakin baik di mata para investor. Penelitian ini didukung oleh Fridagustina (2014), Hariarti \& Rihatiningtyas (2015), serta Astutik (2021). Interpretasi praktis penelitian ini adalah perusahaan supaya fokus terhadap CSR supaya menjadi daya pikat calon investor untuk menanamkan modalnya diperusahaan tersebut.

\section{Pengaruh Kinerja Keuangan terhadap Nilai Perusahaan}

Hasil uji hipotesis, kinerja keuangan secara positif signifikan berpengaruh pada nilai perusahaan, sehingga H6 diterima. Penelitian ini didukung signaling theory yang menjelaskan kinerja keuangan dapat menjadi suatu koneksi tentang peluang perusahaan sesuai dengan tingkat laba yang dibentuk. 
Metalaras Saputri \& Yuyun Isbanah. Pengaruh Good Corporate Governance dan Corporate Social Responsibility terhadap Nilai Perusahaan dengan Kinerja Keuangan sebagai Variabel Mediasi pada Perusahaan Misscellaneous Industry di BEI Periode 2016-2019

Karena dengan adanya kenaikan laba maka akan menjadi acuan untuk pengambilan keputusan investasi bagi para investor (Maryanto, 2017). Pada penelitian ini jumlah rata-rata persentase ROA perusahaan misscellaneous industry di BEI periode 2016-2019 adalah sebesar 6\%, berarti perusahaan dapat dikatakan baik dan sehat karena jumlah ROA >2\%. Hal tersebut menunjukkan bahwa kemampuan perusahaan untuk mendapatkan laba bersih semakin tinggi dibandingkan penggunaan aktiva perusahaan. Maka dari itu, calon investor akan yakin berinvestasi. Menurut Ernawati (2017), dan Maryanto (2017), dengan tingkat risiko keuangan yang diperoleh oleh entitas maka bisa menunjukkan respon baik dari pasar yang dampaknya pada peningkatan nilai perusahaan yang disebabkan oleh naiknya harga saham. Interpretasi praktis dari hasil ini adalah bahwa perusahaan harus fokus pada kinerja keuangan untuk menjalin hubungan yang baik dengan investor.

\section{Pengaruh Kepemilikan Manajerial terhadap Nilai Perusahaan dengan Kinerja Keuangan sebagai Variabel Mediasi}

Hasil tes sobel menunjukkan kinerja keuangan belum mampu memediasi pengaruh kepemilikan manajerial terhadap nilai perusahaan, sehingga $\mathrm{H} 7$ ditolak. Hasil ini tidak mendukung agency theory, kepemilikan saham manajemen bisa menjadikan pihak manajemen berindak sesuai dengan kemauan pihak investor (Astutik, 2021). Namun karena rasio kepemilikan saham rata-rata yang rendah yaitu sebesar 8\%, manajemen belum bisa bekerja sesuai harapan investor. Selain itu, dalam penelitian ini kepemilikan saham manajemen tidak bisa menambah keuntungan perusahaan. Ini karena manajemen memegang sebagian kecil saham. Karena manajemen bukanlah pemegang saham utama perusahaan, masalah keagenan dapat terjadi. Penelitian ini sejalan dengan Astutik (2021). Interpretasi sebenarnya dari hasil ini adalah bahwa perusahaan telah meningkatkan kapasitas kepemilikan saham manajemen perusahaan, sehingga manajer bisa memantau prospek perusahaan dan berpartisipasi dalam pengambilan keputusan dan investor terbaik tentang kemajuan perusahaan.

\section{Pengaruh Kepemilikan Institusional terhadap Nilai Perusahaan dengan Kinerja Keuangan sebagai Variabel Mediasi}

Kinerja keuangan belum bisa memediasi pengaruh kepemilikan institusional pada nilai perusahaan, sehingga H8 ditolak. Penelitian ini mendukung agency theory, bahwa terdapat ketidaksesuaian informasi antara manajemen dan pemilik perusahaan (Astutik, 2021). Hal ini disebabkan manajer dapat melaksanakan interaksi langsung dengan perusahaan sehingga memeroleh data yang cukup serta mendalam perihal perusahaan yang dioperasikan. Namun, owner perusahaan tidak bisa turun langsung untuk melaksanakan interaksi dengan perusahaan, hanya dapat mengantungkan laporan keuangan yang diterima dari manajer, sehingga owner perusahaan memiliki data yang sedikit dibanding dengan manajer. Akan tetapi, data penelitian menunjukkan bahwa rata-rata rasio kepemilikan saham institusional cenderung lebih tinggi sebesar 58\% yang menyebabkan kurangnya sinergi antara kepentingan manajer dan investor sehingga menghambat perusahaan saat meraih tujuan utamanya, yaitu menaikkan nilai perusahaan. Penelitian ini sejalan dengan Sukirni (2012), serta Thaharah \& Asyik (2016). Interpetasi praktis hasil ini untuk meningkatkan nilai perusahaan, perusahaan harus fokus terhadap kepentingan bersama.

\section{Pengaruh Komite Audit terhadap Nilai Perusahaan dengan Kinerja Perusahaan sebagai Variabel Mediasi}

Kinerja keuangan belum bisa memediasi pengaruh komite audit terhadap nilai perusahaan, sehingga H9 ditolak. Hasil tidak sesuai agency theory, komite audit dalam perusahaan sangat dibutuhkan untuk mengurangi kekurangan yang dilaksanakan oleh pihak manajemen (Astutik, 2021). Menurut Syafitri et al. 2018), total komite audit belum bisa menjadi jaminan keefektifan dari kinerja komite audit saat melaksankan kontrol terhadap kinerja keuangan. Hal itu dikarenakan komite audit tidak hanya melakukan pengawasan di bidang keuangan namun juga melakukan pengawasan di bidang non keuangan serta melaksanakan rapat secara periodik untuk memertahankan citranya dimata para investor. Peraturan OJK No 55/POJK.04/2015 yang mengatur sekurang-kurangnya 3 orang anggota komite audit sehingga, dalam penelitian ini jumlah komite audit belum dapat menjadi acuan untuk dapat menaikkan keuntungan perusahaan. Penelitian ini sejalan dengan Syafitri et al. (2018). Interpretasi praktis penelitian adalah supaya perusahaan memfokuskan komite audit untuk bekerja 
secara komplek dengan melihat keefektifan pada proses pengambilan keputusan dapat memberikan dukungan untuk meningkatkan nilai perusahaan dan kualitas laporan keuangan.

\section{Pengaruh Dewan Komisaris Independen terhadap Nilai Perusahaan dengan Kinerja Keuangan sebagai Variabel Mediasi}

Kinerja keuangan belum bisa memediasi pengaruh dewan komisaris independen pada nilai perusahaan, maka dari itu H10 ditolak. Hasil ini tidak mendukung agency theory, dewan komisaris independen mampu menangani permasalahan kelompok dikarenakan tugas pengendalian yang dilaksanakan objektif pada pengelolaan manajemen berkaitan dengan kinerja keuangan (Astutik, 2021). Menurut regulasi Otoritas Jasa Keuangan jumlah anggota dewan komisaris independen belum mampu menghasilkan dampak terhadap kinerja keuangan dan nilai perusahaan. Hal itu disebabkan perusahaan sulit saat melaksanakan pengambilan keputusan karena banyaknya pertimbanganpertimbangan yang dikemukakan oleh anggota dewan komisaris independen. Pada data penelitian jumlah anggota dewan komisaris independen adalah 5-7 orang. Sehingga, jika dewan komisaris independen berjumlah banyak dirasa kurang efektif dalam pengambilan keputusan yang bertujuan untuk meningkatkan laba dan nilai perusahaan. Sehingga dengan banyaknya anggota dewan komisaris independen maka rawan terjadi konflik atau selisih paham antar anggota. Penelitian ini sejalan dengan Astutik (2021). Interpretasi praktis hasil ini adalah untuk meningkatkan nilai perusahaan, perusahaan harus fokus dalam pengambilan keputusan.

\section{Pengaruh CSR terhadap Nilai Perusahaan dengan Kinerja Keuangan sebagai Variabel Mediasi}

Kinerja keuangan bisa memediasi pengaruh CSR terhadap nilai perusahaan, sehingga H11 diterima. Hasil ini mendukung stakeholder theory yang menjelaskan dalam upayanya untuk dapat meningkatkan nilai perusahaan masa mendatang maka perusahaan harus berperilaku etis dalam melaksanakan tanggung jawab sosial di lingkungan sekitar, sehingga akan menghasilkan dampak positif serta mencerminkan keuntungan dari perusahaan (Ghozali \& Chariri, 2007). Dalam penelitian ini perusahaan mampu meningkatkan citra dan target pasar perusahaan yang bisa menaikkan keuntungan dari penjualan perusahaan Keuntungan perusahaan adalah sarana bagi investor untuk berinvestasi. Penelitian ini sejalan dengan penelitian Putra (2015), dengan meningkatnya nilai perusahaan maka pengungkapan informasi sosial semakin banyak. Pada penelitian ini pengungkapan CSR yang dilakukan perusahaan rata-rata adalah $16 \%$. Oleh karena itu, jika tanggung jawab sosial perusahaan naik sehingga nilai perusahaan juga mengalami peningkatan. Selain itu, CSR juga menunjukkan tanggung jawab pada lingkungan sekitar, dan berdampak baik dalam waktu panjang yang tercermin pada manfaat perusahaan dan dapat meningkatkan kinerja perusahaan. Interpretasi praktis hasil penelitian ini adalah supaya perusahaan mempertahankan citranya dengan tetap melakukan tanggung jawab sosial yang lebih bermanfaat bagi stakeholder, shareholder dan lingkungan sekitarnya.

\section{KESIMPULAN}

Berdasarkan hasil pembahasan di atas dapat disimpulkan komite audit (KA) berpengaruh terhadap nilai perusahaan karena perusahaan memiliki jumlah komite audit yang sesuai dengan peraturan OJK No 55/POJK.04/2015 yang mengatur sekurang-kurangnya 3 orang anggota komite audit, sehingga dapat bekerja maksimal dalam bidang pengawasan dan pelaksanaan rapat secara periodik. CSR berpengaruh terhadap nilai perusahaan karena perusahaan telah melakukan pengunggkapan tanggung jawab sosial yang cukup tinggi terhadap masyarakat sekitar, sehingga perusahaan mampu memertahankan citra positif pada stakeholder dan shareholder. Kepemilikan manajerial (KM) tidak berpengaruh terhdap nilai perusahaan karena jumlah saham pihak manajemen relatif kecil singga tidak dapat bertindak sesuai keinginan para investor. Kepemilikan institusional (KI) tidak berpengaruh terhadap nilai perusahaan karena jumlah saham oleh pihak institusional relatif tinggi sehingga memungkinkan pihak pemegang saham lebih mengutamakan kepentingan sendiri dari pada kepentingan bersama. Dewan komisaris independen (DKI) tidak perngaruh terhadap nilai perusahaan karena banyaknya jumlah anggota komisaris independen sehingga perusahaan sulit dalam pengambilan keputusan dikarenakan banyaknya pertimbangan. Kinerja keuangan berpengaruh 
Metalaras Saputri \& Yuyun Isbanah. Pengaruh Good Corporate Governance dan Corporate Social Responsibility terhadap Nilai Perusahaan dengan Kinerja Keuangan sebagai Variabel Mediasi pada Perusahaan Misscellaneous Industry di BEI Periode 2016-2019

terhadap nilai perusahaan karena nilai ROA $>2 \%$ di mana perusahaan dapat dikatakan sehat dalam segi keuangan sehingga dapat menarik minat para investor untuk berinvestasi yang berdampak pada peningkatan laba dan niai perusahaan. Kinerja keuangan sebagai variabel mediasi yang diproksikan oleh ROA hanya mampu memediasi pengaruh CSR terhadap nilai perusahaan karena perusahaan memberikan citra baiknya kepada stakeholder dan shareholder untuk meningkatkan keuntungan yang berdampak terhadap naiknya nilai perusahaan. Kinerja keuangan sebagai variabel mediasi yang diproksikan oleh ROA tidak mampu memediasi pengaruh kepemikan manajerial (KM), kepemilikan institusional (KI), komite audit (KA), serta dewan komisaris independen (DKI) karena perusahaan belum secara maksimal membentuk tata kelola perusahaan yang baik sehingga selalu bertentangan dengan teori keagenan yang mengakibatkan sulit untuk perusahaan meningkatkan keuntungan dan nilai perusahaan.

Implikasi manajerial, untuk dapat meningkatkan nilai perusahaan perlu memerhatikan GCG dan CSR. Bagi investor diharapkan dapat memberikan dampak pada keputusan investasi yang akan berpengaruh terhadap nilai perusahaan. Penelitian ini memliki keterbatasan variabel, oleh sebab itu penelitian selanjutnya dapat menambahkan beberapa variabel antara lain dewan direksi, kepemilikan keluarga, dan kualitas laba.

\section{DAFTAR PUSTAKA}

Afzal, A., \& Rohman, A. (2012). Pengaruh Keputusan Investasi Pendanaan dan Kebijakan Deviden terhadap Nilai Perusahaan. Jurnal Akuntansi Universitas Diponegoro Semarang, 1 No. 1.

Amanti, L. (2012). Pengaruh Good Corporate Governance terhadap Nilai Perusahaan dengan Pengungkapan Corporate Social Responsibility sebagai Variabel Pemoderasi pada Perusahaan Rokok yang Terdaftar Di Bursa Efek Indonesia. Jurnal Akuntansi AKUNESA, 1 No. 1, 1-21.

Ardianto, E., \& Machfudz, D. M. (2011). Efek Kedermawan Pebisnis dan CSR. Jakarta: Kompas Gramedia.

Astutik, E. M. (2021). Faktor-Faktor yang Memengaruhi Nilai Perusahaan dengan Profitabilitas sebagai Variabel Mediasi pada Sektor Pertambangan Di BEI Tahun 2015-2018. Jurnal Ilmu Manajemen, 9 No.1.

Brigham, E., \& Houston, J. (2006). Dasar-Dasar Manajemen Keuangan, Edisi 10. Jakarta: Salemba Empat.

Chen. (2008). Does Institutional Ownership creat value? The New Zaeland Case. Quarterly Journal of Finance and Accounting, 47 (4), 109-124.

Chrisdianto, B. (2013). Peran Audit dalan Good Corporate Governance. Jurnal Akuntansi Akrual, 2 No 1, 1-8.

Dewi, L. C., \& Nugrahanti, Y. W. (2017). Pengaruh Stuktur Kepemilikan dan Dewan Komisaris Independen terhadap Nilai Perusahaan (Studi pada Perusahaan Industri Barang Konsumsi di BEI Tahun 2011-2013). Journal of Business and Economic, 18 (1), 64-75.

Dian, F., \& Lidyah, R. (2012). Pengaruh Corporate Social Responsibility, Kepemilikan Manajerial, dan Kepemilikan Institusional terhadap Nilai Perusahaan Tambang Batu Bara yang terdaftar di BEI. Jurnal STIE MDP, 1-10.

Effendi, M. A. (2016). The Power of Corporate Governance Teori dan Implementasi (2nd ed.). Jakarta: Salemba Empat. 
Ernawati, Y. (2017). Reconstruction of Financial Perfomance to Manage Gap Between Value Added Intellectual Coefficient (VAICTM) and Value of Company in Banking Company Listed in Indonesia Stock Exchange. International Journal of Economic and Financial, 7 (4), 537-549.

Fahmi, I. (2011). Analisi Laporan Keuangan. Bandung: Alfabeta.

Fakhrudin, M., \& Hadianto, M. S. (2001). Perangkat dan Model Analisis Investasi di Pasar Modal. Dalam Buku Satu. Jakarta: PT. Erlangga.

Fatimah, Mardani, R. M., \& Wahono, B. (2019). Pengaruh Good Corporate Governance terhadap Nilai Perusahaan dengan Kinerja Keuangan sebagai Variabel Intervening (Studi Kasus Pada Perusahaan Manufaktur Sektor Barang). Jurnal Ilmiah Riset Manajemen, 8 No.15, 51-69.

Fridagustina, K. (2014). Pengaruh Stuktur Kepemilikan Saham dan Corporate Social Responsibility pada Nilai Perusahaan. Buletin Studi Ekonomi, 18 No.2, 85-190.

Ghozali, \& Chariri. (2007). Teori Akuntansi. Semarang: Badan Penerbit Undip.

Hadi, N. (2011). Corporate Social Responsibility. Yogyakarta: Graha Ilmu.

Haniffa, R. M. (2005). The Impact of Culture and Governance on Corporate Social Reporting. Journal of Accounting and Public Policy 24, 391-430.

Hariarti, I., \& Rihatiningtyas. (2015). Pengaruh Tata Kelola Perusahaan dan Kinerja Lingkungan Terhadap Nilai Perusahaan. Jurnal Ilmu Mahasiswa FEB, 3 No. 2, 1-12.

Haryati, R., \& Raharjo, S. N. (2013). Pengaruh Corporate Social Responsibility, Kinerja Lingkungan, dan Struktur Corporate Governance terhadap Kinerja Keuangan Perusahaan yang Terdaftar di BEI. Diponegoro Journal of Accounting, 2 No. 2, 1-15.

Husnan, A., \& Pamudji, S. (2013). Pengaruh Corporate Social Responsibility (CSR Disclosure) Terhadap Kinerja Keuangan Perusahaan. Diponegoro Journal of Accounting, 2 No. 2, 1-8.

Irawan, N., \& Devie. (2017). Pengaruh Corporate Governance terhadap Firm Value dengan Financial Performance sebagai Variabel Intervening Pada Perusahaan LQ 45 Tahun 2012-2015. Jurnal Akuntasi, 5 (1), 277-288.

Iskandar, \& Chamlou. (2000). Corporate Governance-A Framework For Implementation. Washington DC, USA: The World Bank.

Isti'adah, U. (2015). Management Control System (11 Buku 2). Jakarta: Salemba Empat.

Jensen, M. C. (1976). Theory of the Firm. Journal of Financial Economic, 3 (1), 305-360.

Juwita, R. (2019). The Effect of Corporate Goveranace and Family Ownership on Firm Value. Review of Integrative Business \& Economics Reseach, 8 (1), 168-178.

Krisnando, \& Sakti, S. H. (2019). Pengaruh Good Corporate Governance dan Ukuran Perusahaan terhadap Nilai Perusahaan dengan Kinerja Keuangan Sebagai Variabel Moderasi. Jurnal Akuntansi dan Manajemen, 16 No. 01, 73-95.

Kristanti, M., \& Syafuddin, M. (2012). Pengaruh Karakteristik Komite Audit Pada Kondisi Financial Distress Perusahaan. Jurnal Akuntansi Fakultas Ekonomika Dan Bisnis Universitas Diponegoro, 1 (1), 275-288. 
Metalaras Saputri \& Yuyun Isbanah. Pengaruh Good Corporate Governance dan Corporate Social Responsibility terhadap Nilai Perusahaan dengan Kinerja Keuangan sebagai Variabel Mediasi pada Perusahaan Misscellaneous Industry di BEI Periode 2016-2019

Kusumaningtyas, T. K. (2015). Pengaruh Good Corporate Governnace terhadap Nilai Perusahaan yang Terdaftar Pada Indeks Sri-Kehati. Jurnal Ilmu dan Riset Akuntansi, 4 NO 7, 1-16.

Lindenberg, E. B., \& Ross, S. A. (1981). Tobin's q Ratio and Industrial Organization. Journal of Bussiness, 54 (1), 1-32.

Mahendra , A. (2011). Pengaruh Kinerja Keuangan terhadap Nilai Perusahaan (Kebijakan Deviden Sebagai Variabel Moderating) Pada Perusahaan Manufaktur di BEI. Jurnal Manajemen dan Bisnis, 6 No. 2, 130-138.

Mai, M. U. (2017). Mediation Of CSR and Profitabilitas On the Influences Of GCG Mechanisms to the Firm Value. Jurnal Keuangan dan Perbankan, 21 No.2, 253-264.

Marius, M. E., \& Masri, I. (2017). Pengaruh Good Corporate Governance dan Corporate Social Responsibility terhadap Nilai Perusahaan. Jurnal Mahasiswa Teknologi Pendidikan, 2 No.3, 1 22 .

Maryanti, E., \& Fithri, W. N. (2017). Corporate Social Responsibility, Good Corporate Governance, Kinerja Lingkungan terhadap Kinerja Keuangan dan Pengaruhnya Pada Nilai Perusahaan. Journal Of Accounting Science, 1 No.1, 21-37.

Maryanti, E., \& Tjahjadi, B. (2013). Analisis dan Corporate Social Responsibility, Good Corporate Governance terhadap Kinerja Keuangan yang Mempengaruhi Nilai perusahaan Manufaktur yang Terdaftar di BEI. JEBA, Vol 23 No 1.

Maryanto, H. K. (2017). Pengaruh Intelletual Capital dan Good Corporate Governance terhadap Nilai Perusahaan dengan Kinerja Keuangan sebagai Variabel Intervening. JOM, 4 (1), 1598-1612.

Meridelima, E., \& Isbanah, Y. (2021). Analisis Faktor-Faktor Yang Memengaruhi Keputusan Hedging Perusahaan Sektor Industri Pengolahan Yang terdaftar di BEI Tahun 2014-2018. Jurnal Ilmu Manajemen, 9 No. 1.

Modigliani, F., \& Miller , M. (1958). The Cost of Capital, Corporation Finance ang The Theory of Invesment. The American Economic Review, 261-297.

Monks, R. A., \& Minow, N. (2003). Corporate Governance 3rd Edition. Blackwell Publishing.

Muid, D. (2009). Pengaruh Mekanisme Corporate Governance terhadap Kualitas Laba. Diponegoro Journal of Accounting, 4 No 2, 94-108.

Mukhtaruddin, Relasari, \& Felmania, M. (2014). Good Corporate Governance Mechanism, Corporate Social Responsibility Disclosure on Firm Value: Emperical Study on Listed Company in Indonesia Stock Exchange. Internaional Journal of Finance \& Accounting Studies, 2 (1), 1-10.

Nova, F. (2012). Re Public Relations. Jakarta: Media Bangsa.

Nuraina, E. (2012). Pengaruh Kepemilikan Institusional dan Ukuran Perusahaan terhadap Kebijakan Hitang dan Nilai Perusahaan (Studi Pada Perusahaan Manufaktur yang Terdaftar di BEI). Jurnal AKRUAL, 4 (1), 51-70.

Nurhayati, \& Medyawati. (2012). Analisis Pengaruh Kinerja Keuangan, Good Corporate Governance dan Corporate Social Responsibility terhadap Nilai Perusahaan yang Terdaftae dalam LQ45 Pada Tahun 2009-2011. Jurnal Akuntansi, 1-13. 
Obradovich, J. (2013). The Impact of Corporate Governance and Financial Leverage on the Value of American Firms. International Research Journal of Financial and Economics(91 (2012)), 1-15.

Permanasari, I. (2010). Pengaruh Kepemilikan Manajemen, Kepemilikan Institusional, dan Corporate Social Responsibility terhadap Nilai Perusahaan. Jurnal Nominal, 2 No.2.

Pertiwi, T. K., \& Pratama, F. M. (2012). Pengaruh Kinerja Keuangan, Good Corporate Governance terhadap Nilai Perusahaan Food and Beverage. Jurna Manajemen dan Kewirausahaan, 14 (2), 118-127.

Prasatuti, N. K., \& Budiasih, I. A. (2015). Pengaruh Good Corporate Governance Pada Nilai Perusahaan dengan Moderasi Corporate Social Responsibility. E-Journal Akuntasi, 13 No 1, 114-129.

Purbopangestu, H. W., \& Subowo. (2014). Pengaruh Good Corporate Governance terhadap Nilai Perusahaan dengan Corporate Social Responsibility sebagai Variabel Intervening. Accounting Analysis Journal, 3 (3), 321-333.

Puspita. (2011). Analisis Pengaruh Struktur Modal, Pertumbuhan Perusahaan, Ukuran Perusahaan, dan Profitabilitas Terhadap Nalai Perusahaan Pda Perusahaan Manufaktur yang terdaftar di BEI Periode 2007-2009 (Studi kasus pada sektor industri Food and Beverage). Jurnal Ekonomi UNDIP, 1 No. 1 .

Putra, A. (2014). The Impact of Implementation Good Corporate Governance to Firm Value (Evidence from Indonesia Public Banking Sector). Review of Integrative Business \& Economics Research, 4 (1), 95-102.

Putra, A. S. (2015). Pengaruh Corporate Social Responsibility terhadap Profitabilitas Perusahaan, (Studi Empiris Perusahaan Sektor Industri Barang Konsumsi yang Terdaftar di Bursa Efek Indonesia Tahun 2010-2013). Jurnal UNY, 4 No.2, 1-15.

Rachman, A. A. (2012). Pengaruh Corporate Social Responsibility, Kepemilikan Manajerial, dan Kepemilikan Institusional terhadap Nilai Perusahaan pada Perusahaan Manufaktur yang terdatar di BEI tahun 2008-2010. Jurnal Sekolah Tinggi Ilmu Ekonomi Surabaya, 4 (1), 114119 .

Raja, D. H. (2016). Pengaruh Dewan Komisaris, Komisaris Independen, Komite Audit terhadap Profitabilitas pada Perusahaan Sektor Property dan Real Estate yang Terdaftar di Bursa Efek Indonesia (BEI) Tahun 2009-2014. Jurnal Ilmu Manajemen, 4 (2), 139-146.

Ratih, S., \& Setyarini, Y. (2014). Pengaruh Good Corporate Governance (GCG) dan Corporate Social Responsibility (CSR) terhadap Nilai Perusahaan dengan Kinerja Keuangan sebagai Variabel Intervening pada Perusahaan Pertambangan yang Go Public di BEI. AKRUAL (Jurnal Akuntansi), 5 (2), 115-132.

Sari, A. P. (2017). Pengaruh Intellectual Capital dan Corporate Governance terhadap Kinerja Perusahaan. Jurnal Ilmu dan Riset Akuntansi, 6 (7).

Sari, E. F., \& Riduwan, A. (2011). Pengaruh Corporate Governance terhadap Nilai Perusahaan: Kualitas Laba Sebagai Variabel Intervening. Jurnal Ilmu dan Riset Akuntansi, 1 No.1, 1-19.

Sholekah, F. W., \& Venusita, L. (2014). Pengaruh Kepemilikan Manajerial, Kepemilikan Institusional, Leverage, Firm Size dan Corporate Social Responsibility terhadap Nilai Perusahaan pada Perusahaan High Profile yang terdaftar di BEI Perode Tahun 2008-2012. Jurnal Mahasiswa Tegnologi Pendidikan, 2 No. 3, 795-807. 
Metalaras Saputri \& Yuyun Isbanah. Pengaruh Good Corporate Governance dan Corporate Social Responsibility terhadap Nilai Perusahaan dengan Kinerja Keuangan sebagai Variabel Mediasi pada Perusahaan Misscellaneous Industry di BEI Periode 2016-2019

Siahaan, F. O. (2013). The Effect of Good Corpoate Governance Mechanism, Leverage, and Firm Size on Firm Value. GSTF Journal on Business Review (GBR), 4 (3), 66-71.

Sondakh, R., \& Morasa, J. (2019). Ipteks Mengukur Nilai Perusahaan di Pasar Modal Pada Perusahaan yang Terdaftar di Bursa Efek Indonesia. Jurnal Ipteks Akuntansi bagi Masyarakat, 03 No. 01, 17-22.

Sudana, I. M. (2011). Teori \& Praktik Manajemen Keuangan Perusahaan. Jakarta: Erlangga.

Sugiyono. (2013). Metode Penelitian Pendidikan Pendekatan Kuantitatif, Kualitatif, dan R\&D. Bandung: Alfabeta.

Sukirni, D. (2012). Kepemilikan Manajerial, Kepemilikan Institusional, Kebijakan Deviden dan Kebijakan Utang Analisis terhadap Nilai Perusahaan. Accounting Analysis Journal, Vol. 2, No 1, Hal 1-12.

Sunardi, N. (2019). Mekanisme Good Corporate Governance terhadap Nilai Perusahaan dengan Leverage sebagai Variabel Intervening Pada Perusahaan Manufaktur yang Terdaftar Di Bursa Efek Indonesia Tahun 2012-2018. Jurnal Ilmiah Manajemen FORKAMMA, 2 No.3, 48-61.

Suryaningtyas, A., \& Rohman, A. (2019). Pengaruh Penerapan Corporate Governance terhadap Nilai Perusahaan dengan Kinerja Keuangan sebagai Variabel Mediasi. Diponegoro Journal of Accounting, 8 No 4, 1-10.

Susanto, C. M., \& Ardiani, L. (2016). Pengarug Good Corporate Governance, Corporate Social Responsibility, dan Profitabilitas terhadap Nilai Perusahaan. Jurnal Ilmu dan Riset Akuntansi, 5 No 7, 1-17.

Syafitri, T., Nuzula, N. F., \& Nurlaily, F. (2018). Pengaruh Good Corporate Governance terhadap Nilai Perusahaan (Studi pada perusahaan industri sub sektor logam dan sejenisnya yang terdaftar di BEI periode 2012-1016). Jurnal Administrasi Bisnis, 56 No.1, 118-126.

Thaharah, N., \& Asyik, N. F. (2016). Pengaruh Mekanisme Corporate Governance dan Kinerja Keuangan terhadap Nilai Perusahaan LQ 45. Jurnal Ilmu dan Riset Akuntansi, 5 No.2, 1-18.

Untung, H. B. (2008). Corporate Social Responsibility. Jakarta: Sinar Grafika.

Wedayanthi, K. K., \& Darmayanti, N. (2016). Pengaruh Economic Value Added, Komposisi Dewan Komisais Independen dan Return On Assets Terhadap Nilai Perusahaan. E-Jurnal Manajemen Unud, 364-376.

Wedayanthi, K. K., \& Darmayanti, N. (2016). Pengaruh Economic Value Added, Komposisi Dewan Komisais Independen dan Return On Assets terhadap Nilai Perusahaan. E-Jurnal Manajemen Unud, 5 (6), 364-376.

Wibowo, E. (2010). Implementasi Good Corporate Governance di Indonesia. Jurnal Ekonomi dan Kewirausahaan, 10 No. 2, 126-138.

Wiranoto, M. F. (2021). Pengaruh Growth Opportunity, Corporate Social Responsibility, Good Corporate Governance dan Keputusan Invetasi terhadap Nilai Perusahaan (Studi Pada Perusahaan Sektor Property, Real Estate \& Building Contruction Periode 2013-2017). Jurnal Ilmu Manajemen, 9 No 1, 333-345. 
Wongso, A. (2013). Pengaruh Kebijakan Deviden, Struktur Kepemilikan, dan Kebijakan Hutang terhadap Nilai Perusahaan Dalam Prespektif Teori Agensi dan Teori Signaling. Jurnal Ilmiah Mahasiswa Manajemen, 1 (5), 1-20.

Wulan, L. (2016). Profitabilitas Sebagai Pemoderasi Pengaruh Good Corporate Governance pada Nilai Perusahaan. E-Jurnal Akuntansi Universitas Udayana, 14 No.3.

Yahya, M. R. (2014). Pengaruh Opini Audit, Financial Distress, dan Pertumbuhan Perusahaan Klien terhadap Auditor Switching (Studi pada perusahaan manufaktur yang terdaftar di BEI. Jurna Ilmiah Mahasiswa Ekonomi Akuntansi, 1 (1), 81-100.

Yakob, R. (2015). Pengaruh Gender Diversity Dalam Dewan Komisaris, Dewan Komisaris Independen, Ukuran Dewan Komisaris terhadap Perencanaan Pajak. Jurnal Fakultas Ekonomi, 6 No.1, 1-13. 